\title{
Echiodon prionodon, a new species of Carapidae (Pisces, Ophidiiformes) from New Zealand
}

\author{
Eric PARMENTIER \\ Laboratoire de Morphologie Fonctionnelle et Evolutive, Institut de chimie, Bât. B6c, \\ Université de Liège, B-4000 Liège, Belgium. \\ Email: E.Parmentier@ulg.ac.be
}

urn:1sid:zoobank.org:author:18447BB6-9CD7-49D3-8269-553783C3EB2C

\begin{abstract}
A new species of pearlfish, Echiodon prionodon, is described from three specimens. This species is diagnosed by having a serrated margin on the posterior edge of the fangs, expanded thoracic plates on some abdominal vertebrae and ventral swimbladder tunic ridges. This species was only found in coastal waters around the North Island of New Zealand. The diagnosis of Eurypleuron is revised.
\end{abstract}

Key words. Echiodon, Eurypleuron, pearlfish, New Zealand.

Parmentier E. 2012. Echiodon prionodon, a new species of Carapidae (Pisces, Ophidiiformes) from New Zealand. European Journal of Taxonomy 31: 1-8. http://dx.doi.org/10.5852/ejt.2012.31

\section{Introduction}

The Carapidae, which include Pyramodontinae and Carapinae, are eel-like fishes. They range from shallow water to moderately deep waters of the continental slope (Nielsen et al. 1999). Several species belonging to the genera Onuxodon, Carapus and Encheliophis are well known for their unusual behavior of entering and living inside invertebrate hosts such as sea cucumbers, sea stars, or bivalves (Trott 1981). Some Echiodon species could be commensals with sponges or polychaete worm tubes (Nielsen et al. 1999), but it is not proven.

The Echiodontini tribe (Carapinae, Carapidae) comprises three genera (Markle \& Olney 1990). 1) Onuxodon Smith, 1955, with three species, diagnosed by the presence of a rocker bone in front of the swimbladder and a commensal relationships with species of Mollusca (Tyler 1970; Parmentier et al. 2000; Amaoka \& Yoseda 2005). 2) Echiodon Thompson, 1837, comprising a group of 11 valid species (and 1 unnamed larva) found over a depth range of 18-2000 m (Williams 1984a, b; Markle \& Olney 1990; Williams \& Machida 1992; Anderson 2005). This taxon is supported by one synapomorphy: a ventral patch of tunic ridges on the posterior swimbladder (Markle \& Olney 1990). 3) Eurypleuron Markle \& Olney, 1990, characterized by having thoracic plates formed by expanded parapophyses (transverse processes) on the fifth through 18-20th vertebrae (males only) and an exterilium gut supported by elongate, cartilaginous, ventral processes of the coracoid in vexillifer larvae. Markle \& Olney (1990) considered the genus monospecific, Eurypleuron owasianum (Matsubara, 1953), with two major disjunct populations. However, these two populations have differences in $\mathrm{D}_{30}$ counts, precaudal 
vertebral numbers and stomach color. On the basis of these characters and the antitropical distributions (the Northern population is found above $20^{\circ}$ North and Southern population occurs below $20^{\circ}$ South), Williams \& Machida (1992) proposed that these populations correspond to two different species: Eurypleuron owasianum in the north and Eurypleuron cinereum (Smith, 1955) in the south. According to the authors, additional specimens are required to better resolve this issue.

Examination of the collection of carapids held at the Museum of New Zealand Te Papa Tongarewa (Te Papa) revealed three specimens with characters shared by Echiodon and Eurypleuron. The three specimens are here described as a new species and comments on the diagnosis of these genera are given.

\section{Material and methods}

Measurements were made with digital calipers to the nearest $0.1 \mathrm{~mm}$. Information of the axial skeleton was obtained from X-ray digital photographs. The following abbreviations for meristic characters are from Markle \& Olney (1990):

$\mathrm{A}_{30}=$ anal-fin rays anterior to vertical through articulation between vertebrae 30 and 31

$\mathrm{ARDO}=$ anal-fin rays anterior to dorsal-fin origin

$\mathrm{D}_{30}=$ dorsal-fin rays anterior to vertical through vertebrae 30 and 31

$\mathrm{P} 1=$ pectoral-fin rays

$\mathrm{PCV}=$ precaudal vertebrae

$\mathrm{VAO}=$ vertebrae to anal-fin origin

$\mathrm{VDO}=$ vertebrae to dorsal-fin origin

$\mathrm{VPB}=$ vertebra number under predorsal bone

Other abbreviations are:

HL $=$ head length

$\mathrm{TL}=$ total length

FAKU $=$ Faculty of Agriculture, Kyoto University

NMNZ $=$ Museum of New Zealand Te Papa Tongarewa

RUSI = Rhodes University, J.L.B. Smith Institute of Ichthyology, Grahamstown

ZMUC $=$ Zoological Museum of the University of Copenhagen

The present specimens were compared with Echiodon cryomargarites Markle, Williams \& Olney, 1983 (NMNZ P016530, NMNZ P016537), Echiodon pegasus Markle \& Olney, 1990 (NMNZ P016529, NMNZ P020999), Echiodon rendahli (Whitley, 1941) (NMNZ P014855) and with radiographs of Echiodon neotes Markle \& Olney, 1990 (ZMUC P77815), Eurypleuron cinereum (RUSI 309) and Eurypleuron owasianum (FAKU 34517, 34518, 34519). 


\title{
Results
}

\author{
Class Actinopterygii Klein, 1885 \\ Order Ophidiiformes Berg, 1937 \\ Family Carapidae Jordan \& Fowler, 1902 \\ Genus Echiodon Thompson, 1837 \\ Echiodon prionodon sp. nov. \\ urn:1sid:zoobank.org:act:44A01315-F569-4553-B342-69C5D1C51ACF
}

Figs 1-4

\section{Diagnosis}

A species of Echiodon, with a serrated posterior margin on the fangs, expanded thoracic plates on some abdominal vertebrae, PCV $33-35, \mathrm{D}_{30} 42-45, \mathrm{~A}_{30} 40-41$.

\section{Etymology}

From the Greek priôn meaning saw, and odous (odon) meaning tooth, in reference to the unique morphology of the fang at the tip of the jaw.

\section{Type material}

\section{Holotype}

ô, 165 mm TL, in NMNZ (P.041833), RV Tangaroa, sta. TAN 0413/119, 13 Nov. 2004.

\section{Paratypes}

NMNZ P.003281 (97 mm TL), off Kapiti Island, 4051.0'S - 17452.0'E, Fred Abernethy, $37 \mathrm{~m}$, Apr. 1958, badly cleared and stained specimen; NMNZ P.052493 (57+ mm, anterior portion only),

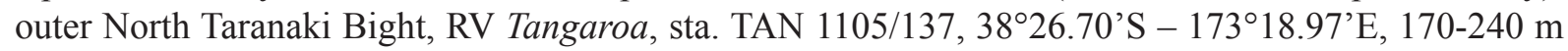
epibenthic sled, 5 Apr. 2011.

\section{Type locality}

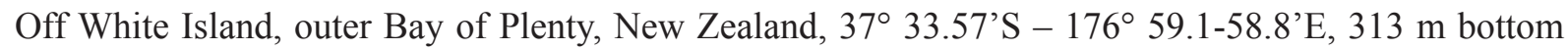
trawl.

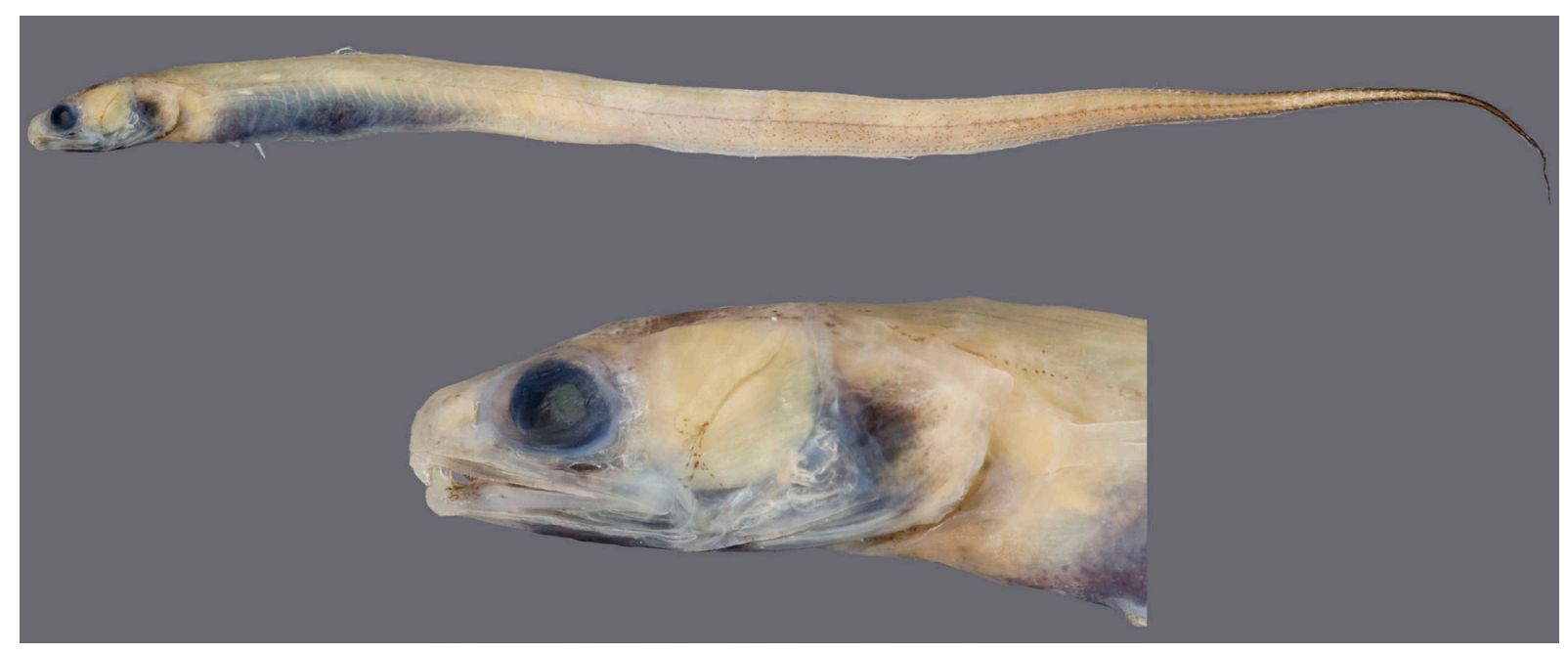

Fig 1. Echiodon prionodon sp. nov., left lateral view (holotype NMNZ P.041833, 165 mm TL). 
Table 1. Morphometric (mm) and meristic data for Echiodon prionodon sp. nov. Numbers in brackets refer to measurements in $\%$ head length.

\begin{tabular}{|l|c|c|c|}
\hline & $\begin{array}{c}\text { NMNZ } \\
\mathbf{P . 0 4 1 8 3 3} \\
\text { Holotype }\end{array}$ & $\begin{array}{c}\text { NMNZ } \\
\text { P.003281 } \\
\text { Paratype }\end{array}$ & $\begin{array}{c}\text { NMNZ } \\
\text { P.052493 } \\
\text { Paratype }\end{array}$ \\
\hline Total length (mm) & 165 & 97 & - \\
\hline Head length & 17.8 & 12.8 & 12.5 \\
\hline Preanus length & $21.1(118)$ & $14.9(116)$ & $15.4(123)$ \\
\hline Predorsal length & $26.3(147)$ & $15.8(123)$ & $17.8(142)$ \\
\hline Snout length & $2.5(14)$ & $2.0(15)$ & $2.2(17)$ \\
\hline Upper jaw length & $7.8(44)$ & $5.9(46)$ & $6.0(48)$ \\
\hline Lower jaw length & $9.3(52)$ & $6.4(49)$ & $6.8(54)$ \\
\hline Horizontal eye diameter & $4.1(23)$ & $3.3(25)$ & $2.9(23)$ \\
\hline Head depth & $6.9(39)$ & $5.3(41)$ & - \\
\hline Depth at anus & $8.4(47)$ & $5.8(45)$ & $6.3(50)$ \\
\hline Interorbital length & $2.2(12)$ & $1.4(11)$ & $1.5(12)$ \\
\hline Pectoral length & $8.7(49)$ & - & $8.2(65)$ \\
\hline \multicolumn{1}{|c|}{ Meristic } & & & 35 \\
\hline PCV & 33 & 33 & - \\
\hline $\mathrm{D}_{30}$ & 45 & 42 & 41 \\
\hline $\mathrm{A}_{30}$ & 40 & - & 7 \\
\hline VDO & 8 & 8 & 7 \\
\hline VAO & 7 & 6 & 13 \\
\hline VPB & 7 & - & 14 \\
\hline $\mathrm{P}_{1}$ & 15 & & \\
\hline
\end{tabular}

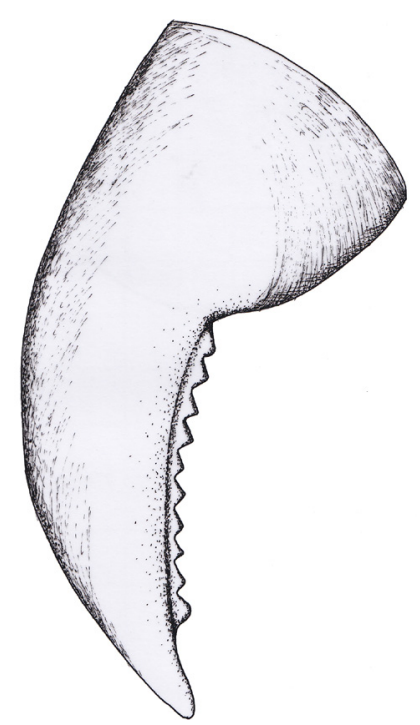

Fig. 2. Echiodon prionodon sp. nov., left lateral view of the left premaxillary fang showing the posterior serrated margin. 


\section{Description}

Selected counts and measurements are given in Table 1 and the holotype is shown in Figure 1. Body slender, much higher than wide, tapering into a pointed tail; greatest body depth (at anus) approximately $5 \%$ of total length; no caudal fin; dorsal fin origin posterior to anal fin origin, anus ends in a tube at half length of the pectoral fin. Dorsal profile of head slightly convex. Snout rounded in lateral view, slightly projecting beyond upper jaw. Olfactory lobe approximately $70 \%$ of snout length, closer to the eye than to the snout tip; anterior nostril developed in a small tube; posterior nostril directly in front of anterior margin of eye, elliptical, being higher than long. Eye elongate, longer than high. Mouth oblique, upper jaw extending beyond posterior margin of eye; posterior portion of maxilla unsheathed. Anterior tip of lower jaw behind tip of snout, lower jaw occlusion with palatine bones. Short opercular spine exposed through an elliptical slit in skin. Gill opening extends from upper end of pectoral fin base to below rear end of maxillary. Seven branchiostegal rays. Ceratobranchials 1 with three slender gill-rakers, with tooth pads on upper limb; other gill-rakers tubercular.

Two enlarged caniniform teeth near symphysis in premaxilla and in dentary (one tooth missing on left lower jaw in holotype). Each of these caniniform teeth has a serrated margin posteriorly (Fig. 2). Upper and lower jaw fangs are separated from the posterior teeth rows by a pronounced diastema. Eight to nine rows of small, minute, straight, conical teeth on dentary, 3-4 outer rows with smaller teeth. Four to five rows of small conical teeth on the upper jaw, teeth on inner rows somewhat longer and curved inwardly, teeth of outer rows similar to lower jaw teeth. Palatine with 4-5 rows of villiform teeth. Vomer a small oblong bump with irregular disposition of small conical teeth, posterior one being somewhat bigger. In the holotype (Fig. 3), vertebral centra 6 to 24 with parapophyses expanded to form lateral plates (vertebral centra 6 to 14 in NMNZ P.052493, 6 to 17 in NMNZ P.003281). Holotype swimbladder extends to $30^{\text {th }}$ vertebral centra ( $57.9 \mathrm{~mm}$ from the snout tip), slight central constriction separating anterior part, brown with dark spots, and shorter posterior part, unpigmented and with ventral tunic ridges.

\section{Color pattern}

After eight years in alcohol, the holotype has cream-colored body and head. Melanophores highly concentrated at the level of the geniohyoideus (throat), but not on the lower jaws, at the oro-branchial cavity on the tongue, the palate, branchial arches, on the inner face of the opercula, on the parietals and on the posterior parts of the frontal. Stomach and peritoneal cavity black, anus unpigmented. Melanophores concentrated at the base of dorsal and anal fins and forming lines on the lateral lines and on different myosepta. Pterygiophores of anal and dorsal fins black from the tip to approximately $1 / 5$ of the body length.

\section{Differential diagnosis}

Echiodon prionodon sp. nov. is unique in having serrated posterior margin on the fangs. Moreover, it differs from all others Echiodon species by the thoracic plates on some abdominal vertebrae and it differs from Eurypleuron species by having tunic ridges on the swimbladder.

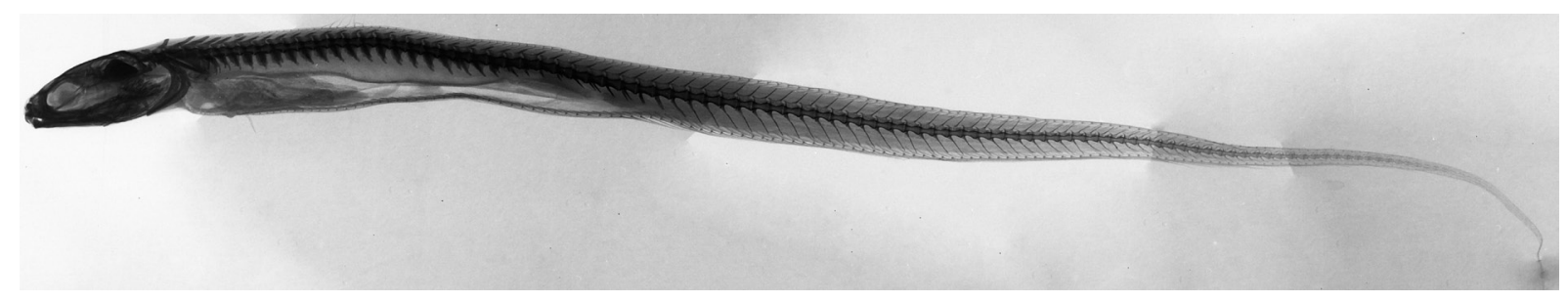

Fig. 3. Echiodon prionodon sp. nov., left lateral X-ray (holotype NMNZ P.041833, 165 mm TL). 


\section{Distribution}

Endemic to coastal waters around the North Island of New Zealand (Fig. 4). The species seems to be benthic from 30 to $315 \mathrm{~m}$ depth. The holotype was caught along with other fish species which usually are associated with shelly-gravel to sandy bottoms with patch reefs as Gnathophis umbrellabius (Whitley, 1948) (Congridae), Hoplostethus mediterraneus Cuvier, 1829 (Trachichthyidae) and Paraulopus nigripinnis (Günther, 1878) (Paraulopidae).

\section{Discussion}

Echiodon and Eurypleuron are sister genera with similar morphologies (Markle \& Olney 1990). Both have eel-like bodies, one to several large symphyseal fangs on dentary and premaxilla. They lack cardiform teeth, pelvic bones and rocker bone (Nielsen et al. 1999). In the carapid cladogram, Markle \& Olney (1999: fig. 45) noted two non-homoplastic characters in support of Eurypleuron: greatly expanded plate-like parapophyses on centre 5 to 18-22 (males only) and an exterilium gut in larvae. The genus is currently monotypic but Williams \& Machida (1992) recommended more research. They argued, that the genus consists of two species: a Northern Pacific population with Eurypleuron owasianum (Matsubara, 1953) and a Southern Pacific population with Eu. cinereum (Smith, 1955). In Eurypleuron

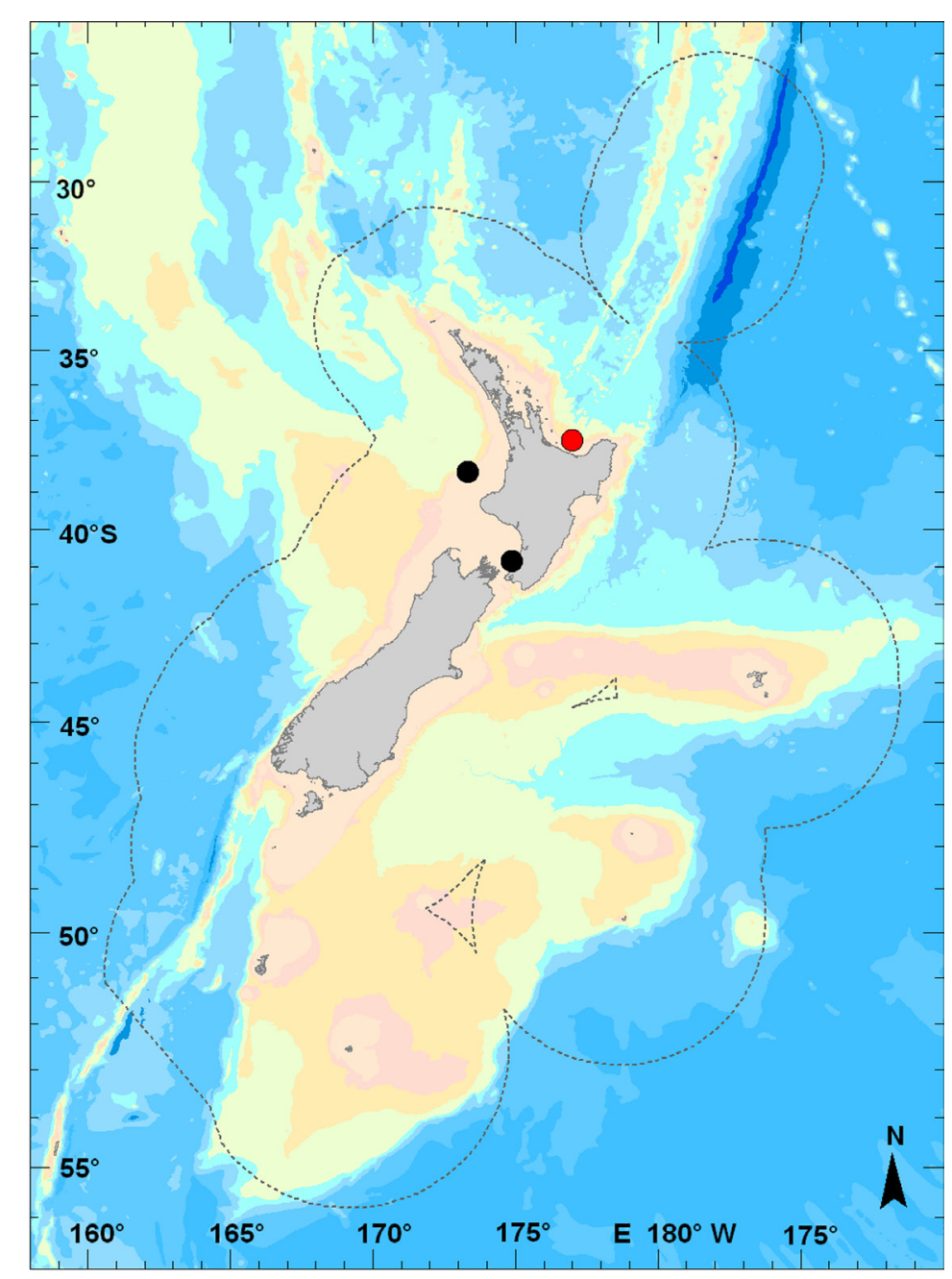

Fig. 4. Distribution of Echiodon prionodon. The red circle depicts the locality where the holotype was caught. 
from both hemispheres, the only autapomorphic character (ventral tunic ridges on the swimbladder) that supports Echiodon was not found.

Echiodon prionodon sp. nov. shows characters of both genera: ventral tunic ridges on the swimbladder and expanded parapophyses. The number of plate-like parapophyses is, however, more variable than in Eurypleuron owasianum (from 8 to 18), which seems related to the size of the fish. I was unable to confirm the sex of the three specimens and therefore cannot confirm if it is a sex-related character. In addition, radiographs do not show the parapophyses expanded in the same way as in Eurypleuron and I conclude that this character results from either convergence or is a homoplastic character.

Many Ophidiiformes use their swimbladder and associated bones to produce sounds (Courtenay \& McKittrick 1970; Parmentier et al. 2002; Fine et al. 2007; Parmentier et al. 2010). Previous anatomical studies showed all the carapids have sound-producing muscles and therefore are able to produce sounds (Parmentier et al. 2002). It is noteworthy that all the characters separating adult Echiodon from Eurypleuron are related to the sound-producing mechanism (Parmentier \& Diogo 2006). This system could play an important role in the speciation process of the group.

Because swimbladder ventral tunic ridges are common to all the Echiodon species, it is more parsimonious to place Ec. prionodon sp. nov. in this genus; otherwise, the genus would be deprived of autapomorphic characters. Moreover, Ec. prionodon sp. nov. shares additional characters with other Echiodon species. It has in common with Ec. drummondi Thompson, 1837, Ec. dentatus (Cuvier, 1829) and Ec. rendahli a central constriction of the swimbladder, with Ec. rendahli a high number of PCV, the same kind of dentition (minute teeth in several rows on both lower and upper jaws) and the same geographic range (Williams 1984a; Markle \& Olney 1990).

More research is required to define the diagnosis of Eurypleuron. The former diagnosis was: thoracic plates formed by expanded parapophyses (transverse processes) on the fifth through 18-20th vertebrae (males only); an exterilium gut supported by elongate cartilaginous ventral processes of the coracoid in vexillifer larvae; lack of ventral tunic ridges on the posterior portion of the swim bladder; dorsal-fin origin over anal-fin origin resulting in equivalent (or almost so) $\mathrm{A}_{30}$ and $\mathrm{D}_{30}$ values (Markle \& Olney 1990). Two characters are now invalid: expanded parapophysis (this study) and the equal $D_{30}$ and $A_{30}$ counts, recently also found in the newly described species Echiodon atopus Anderson, 2005 from the South Atlantic (Anderson 2005).

\section{Acknowledgements}

I am grateful to the Fishes Team of the Museum of New Zealand Te Papa Tongerewa for providing facilities and access to the museum collection. Carl Struthers photographed the holotype and Jeremy Barker made X-rays . Clive Roberts and Andrew Stewart commented on the early draft of this paper.

\section{References}

Amaoka K. \& Yoseda Y. 2005. Two species of pearl fishes, Onuxodon parvibrachium and O. fowleri (Ophidiiformes, Carapidae) from the honeycomb oyster (Hyotissa hyotis), from Ishigaki Island, Okinawa Prefecture. Bulletin of the Biogeographical Society of Japan 60: 5-12.

Anderson M.E. 2005. Description of a new species of Echiodon (Teleostei: Carapidae) from the South Atlantic Ocean. Zootaxa 809: 1-5.

Courtenay W.R. \& McKittrick F.A. 1970. Sound-producing mechanisms in carapid fishes, with notes on phylogenetic implications. Marine Biology 7: 131-137. 
Fine M.L., Lin H., Nguyen B.B., Rountree R.A., Cameron T.M. \& Parmentier E. 2007. Functional morphology of the sonic apparatus in the fawn cusk-eel Lepophidium profundorum (Gill, 1863). Journal of Morphology 268: 953-966. http://dx.doi.org/10.1002/jmor.10551

Markle D.F. \& Olney J.E. 1990. Systematics of the Pearlfish (Pisces: Carapidae). Bulletin of Marine Science 47: 269-410.

Nielsen J.G., Cohen D.M., Markle D.F. \& Robins C.R. 1999. FAO species catalogue. Volume 18. Ophidiiform fishes of the world (order Ophidiiformes). An annotated and illustrated catalogue of pearlfishes, cusk-eels, brotulas and other ophidiiform fishes known to date. FAO Fisheries Synopsis, 125. FAO, Rome.

Parmentier E., Castro-Aguirre J.L. \& Vandewalle P. 2000. Morphological comparison of the buccal apparatus in two bivalve commensal Teleostei: Encheliophis dubius and Onuxodon fowleri (Carapidae, Ophidiiformes). Zoomorphology 120: 29-37. http://dx.doi.org/10.1007/s004359900020

Parmentier E., Chardon M. \& Vandewalle P. 2002. Preliminary study on the ecomorphological signification of the sound-producing complex in Carapidae. In: Aerts P., D'Août K., Herrel A. \& Van Damme R. (eds) Topics in Functional and Ecological Vertebrate Morphology: 139-151. Shaker Publishing, Maastricht.

Parmentier E. \& Diogo R. 2006. Evolutionary trends of swimbladder sound mechanisms in some teleost fishes. In: Ladich F., Collin S.P., Moller P. \& Kapoor B.G. (eds) Communication in Fishes, Vol. I: 43-68. Science Publishers, Enfield.

Parmentier E., Bouillac G., Dragičević B., Dulčić J. \& Fine M.L. 2010. Call properties and morphology of the sound-producing organ in Ophidion rochei (Ophidiidae). Journal of Experimental Biology 213: 3230-3236. http://dx.doi.org/10.1242/jeb.044701

Trott L.B. 1981. A general review of the pearlfishes (Pisces, Carapidae). Bulletin of Marine Science. 31: 623-629.

Tyler J.C. 1970. A redescription of the inquiline carapid fish Onuxodon parvibrachium, with a discussion of the skull structure and the host. Bulletin of Marine Science 20: 148-164.

Williams J.T. 1984a. Studies on Echiodon (Pisces: Carapidae), with description of two new Indo-Pacific species. Copeia 1984 (2): 410-422.

Williams J.T. 1984b. Synopsis and phylogenetic analysis of the pearlfish subfamily Carapinae (Pisces: Carapidae). Bulletin of Marine Science 34: 386-397.

Williams J.T. \& Machida Y. 1992. Echiodon anchipterus: a valid western Pacific species of the pearlfish family Carapidae with comments on Eurypleuron. Japanese Journal of Ichthyology 38: 367-373.

Manuscript received: 29 August 2012

Manuscript accepted: 21 November 2012

Published on: 7 December 2012

Topic editor: Rudy Jocqué

Printed versions of all papers are also deposited in the libraries of the institutes that are members of the EJT consortium: Muséum National d'Histoire Naturelle, Paris, France; National Botanic Garden of Belgium, Meise, Belgium; Royal Museum for Central Africa, Tervuren, Belgium; Natural History Museum, London, United Kingdom; Royal Belgian Institute of Natural Sciences, Brussels, Belgium; Natural History Museum of Denmark, Copenhagen, Denmark 